\title{
The Acceptance of textbooks Writing Poetry-Based Love of The Country
}

\author{
Agung Nasrulloh Saputro*), \\ Universitas PGRI Madiun \\ *) Correspondences author: J1. Setia Budi No.85, Kanigoro, Kartoharjo, Kota Madiun, Jawa Timur 63118; Indonesia \\ e-mail: e-mail: goeng_15@yahoo.co.id
}

\begin{abstract}
This research is a development research that is difficult to develop textbook writing poetry based on love homeland. This development research refers to the Borg Gall stage model. The stage consists of ten stages of development, namely the stage of research and collection of preliminary information, the planning stage, the development stage of the initial production stage initial test phase, product revision phase, field trial phase, product revision stage, field test phase, , and dissemination and implementation. In this study only until the final product revision stage without including the phase of dissemination and implementation due to limited time research. In general, this study aims to explain the process of developing textbooks writing poetry based on love of the homeland. The results of the textbook development process are shown in the following stages. Validas textbooks were assessed by two validators, validation results indicated that the textbooks were included in either category because of the $75 \%$ percentage, the initial trial results were limited to seven class X students generated by student questionnaires, teacher interviews, and observer observations. From the results of field trials, students' grades in writing poetry resulted in an average score of 80 students.
\end{abstract}

Key Words: Development, Poetry Writing, and Love the Fatherland

Article History: Received: 26/10/2017; Revised: 25/11/2017; Accepted: 30/11/2017; Published: 20/12/2017

How to Cite (MLA $7^{\text {th }}$ ): Saputro, Agung Nasrulloh. “The Acceptance of textbooks Writing Poetry-Based Love of The Country." Hortatori Jurnal Pendidikan Bahasa dan Sastra Indonesia 1.2 (2017): 154-159. Print/Online. Copyrights Holder: Saputro, Agung Nasrulloh. First Publication: Hortatori Jurnal Pendidikan Bahasa dan Sastra Indonesia (2017).

This work is licensed under a Creative Commons Attribution-ShareAlike 4.0 International License.

\section{Pendahuluan}

Pembelajaran adalah suatu proses dimana lingkungan seseorang secara disengaja dikelola untuk memungkinkan siswa turut serta dalam tingkah laku tertentu dalam kondisi-kondisi khusus atau menghasilkan respon terhadap situasi tertentu (Sagala, 2011: 61). Guru dengan sadar merencanakan kegiatan pembelajaran secara sistematis demi kepentingan proses belajar mengajar. Belajar adalah suatu proses yang ditandai dengan adanya perubahan pada diri seseorang (Sudjna, 2001: 6). Tanda bahwa seseorang tersebut telah belajar adalah terjadi perubahan tingkah laku yang disebabkan oleh tingkat pengetahuan, keterampilan, dan sikapnya.

Dalam pembelajaran bahasa Indonesia ada empat keterampilan berbahasa yaitu: menyimak, berbicara, membaca, dan menulis. Keempat keterampilan itu sangat erat hubungannya karena pada dasarnya merupakan suatu kesatuan yang utuh. Bahasa seseorang mencerminkan jalan pikiran, semakin terampil seseorang berbahasa maka semakin cerah dan jelas jalan pikirannya (Tarigan, 1986:1). Kejelasan jalan pikiran seseorang merupakan modal utama untuk meraih kesuksesan dan keempat aspek bahasa tersebut untuk penunjang utama bagi keberhasilan seseorang.

Pendidikan merupakan proses memanusiakan manusia, yang artinya bahwa pendidikan merupakan proses untuk mengaktualisasikan semua potensi yang dimilikinya menjadi kemampuan yang dapat dimanfaatkan dalam kehidupan sehari-hari di masyarakat. Proses belajar mengajar merupakan inti dari pendidikan secara keseluruhan dengan guru sebagai pemegang peranan yang utama. Proses belajar 
mengajar dapat dikatakan berhasil apabila materi yang ditunjang oleh sarana prasarana belajar memadai serta metode atu model pembelajaran efektif.

Pembelajaran dikatakan intensif jika apabila tujuan pembelajaran bisa tercapai, artinya setelah pembelajaran selesai siswa mengalami perubahan tingkah laku sebagai hasil dari proses belajarnya. Untuk mencapai hasil yang diharapkan seperti tersebut di muka, peranan guru, media pembelajaran, dan metode pembelajaran sangatlah penting.

Dalam pembelajaran menulis puisi dapat diketahui adanya kesenjangan antara tuntutan dunia pembelajaran menulis puisi dengan keadaan yang ada di lapangan pembelajaran menulis puisi. Ketidakseimbangan tersebut berupa kemampuan siswa dan guru dalam melaksanakan pembelajaran. Antara guru dan siswa seharusnya saling bekerja sama dalam proses belajar mengajar. Dalam pembelajaran tidak bisa guru atau siswa saja yang dominan, keduanya harus saling berperan aktif supaya pembelajaran menulis puisi berjalan dengan baik.

Terjadinya kesenjangan tersebut dapat disebabkan oleh berbagai faktor, diantaranya mengenai (1) faktor pengemasan tujuan pembelajaran apresiasi puisi, (2) perencanaan pembelajaran menulis puisi, (3) strategi dalam pembelajaran menulis puisi, (4) kendala dan upaya guru dalam pembelajaran menulis puisi.

Keberhasilan pembelajaran secara keseluruhan sangat tergantung pada keberhasilan guru merancang materi pembelajaran. Materi Pembelajaran pada hakekatnya merupakan bagian tak terpisahkan dari Silabus, yakni perencanaan, prediksi dan proyeksi tentang apa yang akan dilakukan pada saat Kegiatan Pembelajaran. Secara garis besar dapat dikemukakan bahwa Bahan ajar atau materi pembelajaran (instructional materials) secara garis besar terdiri dari pengetahuan, keterampilan, dan sikap yang harus dipelajari siswa dalam rangka mencapai standar kompetensi yang telah ditentukan. Secara terperinci, jenisjenis materi pembelajaran terdiri dari pengetahuan (fakta, konsep, prinsip, prosedur), keterampilan, dan sikap atau nilai. Oleh karena itu, untuk menunjang ketercapaian pembelajaran, maka peneliti mengembangkan penelitian ini.

Dalam penelitian ini peneliti mengembangkan tiga hal yang berkaitan dengan materi pembelajaran, yaitu silabus, RPP, dan buku siswa. Tujuannya untuk memperbaiki buku siswa yang telah dibuat sebelumnya dari segi isi, kegrafisan, dan penyajian yang berbasis cinta tanah air. Konsep Pendidikan karakter berbasis cinta tanah air merurut Khan (2010: 2) yaitu sikap pribadi, hasil proses kesadaran pemberdayaan cinta tanah air yang diarahkan untuk meningkatkan kualitas pendidikan (konservasi humanis). Jadi penelitian ini akan menghasilkan buku ajar siswa yang mengandung karakter cinta tanah air.

\section{Metode / Method (12pt)}

Penelitian kali ini merupakan penelitian pengembangan karena berusaha mengembangkan materi pembelajaran. Dalam penelitian ini menggunakan kerangka penelitian dari Borg dan Gall (1983: 755) sebagai berikut.

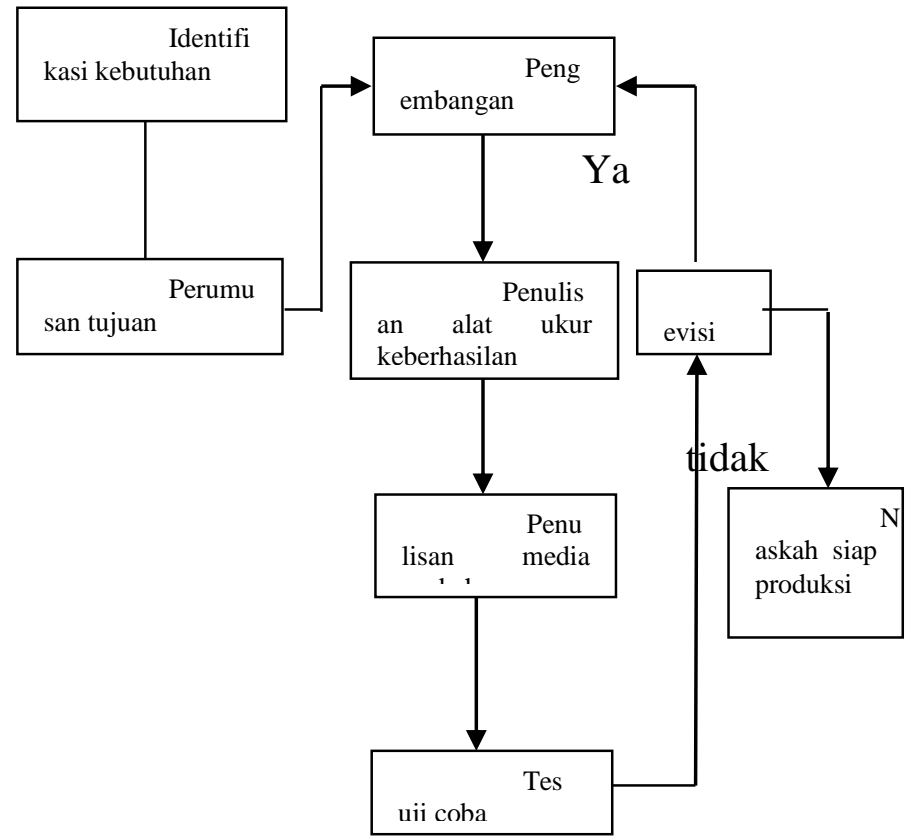

HORATORI | Jurnal Pendidikan Bahasa dan Sastra Indonesia | Vol. 1 No. 2 (2017), 154-159 ISSN 2579-7832 (Print) | ISSN 2579-7840 (Electronic) | Universitas Indraprasta PGRI 
Bagan 1 Model rancangan Pengembangan Borg dan Gall

1. Penelitian dan pengumpulan informasi awal

Penelitian dan pengumpulan informasi yang meliputi kajian pustaka, pengamatan atau observasi kelas, dan persiapan laporan.

2. Perencanaan

Perencanaan, yang mencakup merumuskan kemampuan, merumuskan tujuan khusus untuk menentukan urutan bahan, dan uji coba skala kecil.

3. Pengembangan format produksi awal

Pengembangan format produksi awal, dalam hal ini adalah penembangan materi.

4. Uji coba awal

Uji coba awal menghasilkan data hasil wawancara, observasi, dan angket yang dikumpulkan dan dianalisis.

5. Revisi produk

Revisi produk, yang dikerjakan berdasarkan hasil uji coba awal. Hasil uji coba tersebut diperoleh informasi kualitatif tentang produk yang dikembangkan.

6. Uji coba lapangan

Uji coba awal ini menghasilkan data kuantitatif dari hasil belajar yang dikumpulkan dan dianalisis sesuai dengan tujuan khusus yang dicapai.

7. Revisi produk

Revisi produk, yang dikerjakan berdasarkan hasil uji coba lapangan. Hasil uji coba lapangan dimaksudkan untuk meningkatkan program atau produk untuk perbaikan pada tahap berikutnya

8. Uji lapangan

Uji lapangan ini melibatkan subjek penelitian, disertai wawancara, observasi, dan penyampaian angket dan dianalisis.

9. Revisi produk akhir

Revisi produk akhir, yaitu revisi yang dikerjakan berdasarkan uji coba lapangan.

10. Desiminasi dan implementasi

Desiminasi dan implementasi, yaitu penyampaian hasil pengembangan (proses, prosedur, program, atau produk) kepada para pengguna dan professional melalui forum pertemuan atau menuliskan dalam jurnal, atau dalam bentuk atau handbook.

Karena keterbatasan waktu penelitian, penelitian ini tidak sampai pada desiminasi dan implementasi. Penelitian ini hanya akan menghasilkan revisi produk akhir.

\section{Hasil dan Diskusi}

Penelitian pengembangan ini menggunakan teori Borg dan Gall. Teori ini terdiri atas sepuluh tahap pengembangan, yaitu tahap penelitian dan pengumpulan informasi awal, tahap perencanaan, tahap pengembangan format produksi awal, tahap uji coba awal, tahap revisi produk, tahap uji coba lapangan, tahap revisi produk, tahap uji lapangan, tahap revisi produk akhir, dan desiminasi dan implementasi. Dalam penelitian ini hanya sampai pada tahap revisi produk akhir tanpa menyertakan tahap desiminasi dan implementasi karena keterbatasan waktu penelitian.

Penelitian dan pengumpulan informasi yang meliputi pengamatan atau observasi kelas. Penelitian dan pengumpulan informasi yang meliputi pengamatan atau observasi kelas. Dalam observasi kelas diperoleh data bahwa rasa kreativitas siswa telah luntur. Hal ini dibuktian dengan perilaku siswa (Devi Eka Ariyanin dan Eko Dwiantoro) saat ditanyai oleh guru tentang penyair puisi yang telah berjasa terhadap Indonesia dan jenis majas dalam karya sastra, siswa cenderung banyak yang tidak mengenal nama-nama penyair tersebut. Berdasarkan hasil pengamatan pada tahap penelitian dan pengumpulan informasi awal ini, peneliti berhasil mengumpulkan informasi awal yang berkaitan dengan gejala-gejala yang mempengaruhi ketidakberhasilan siswa dalam pembelajaran khususnya menulis puisi.

Dalam tahap perencanaan ini, peneliti berhasil mengumpulkan data lapangan yang diperoleh dari hasil pengumpulan informasi awal. Data tersebut adalah kurangnya kreativitas dalam hal permajasan, hal 
ini dibuktikan ketika guru bertanya kepada siswa tentang jenis-jenis majas dalam karyta sastra khususnya puisi (Devi Eka Ariyanin dan Eko Dwiantoro) yang tidak mengetahuinya. Hasil pencataan inilah yang melandasi peneliti untuk mengembangkan buku ajar menulis puisi dengan karakter cinta tanah air. Dalam tahap perencanaan ini pula peneliti melakukan pretest, yang berisi tentang pertanyaan-pertanyaan tentang puisi dan majas.Hasil pretest menyebutkan bahwa terdapat 9 siswa yang lulus KKM, yaitu Candra Dyah Ayu Angestiningrum, Lalu Yanuar, Rhamadhan Wisnu, Lily Endra, Imam Arifin A, Faje'ri Indra Tri Hanggara, Devi Eka Ariyani, Riris Hanitasari, dan Candra Dyah. Selebihnya 21 siswa memperoleh nilai di bawah KKM. Selain itu, dalam tahap ini peneliti melakukan tes untuk menentukan subjek penelitian, dan hasilnya kelas XA mendapatkan nilai rata-rata tertinggi dari empat kelas yang dites. Sehingga kelas XA dijadikan sebagai subjek penelitian..

Pengembangan format produksi awal, dalam hal ini adalah pembuatan buku ajar menulis puisi dengan berbasis cinta tanah air dan menilaikan buku ajar kepada dua validator, yaitu validator pembelajaran bahasa Indonesiadan validator desain grafis. Hasil analisis buku ajar menulis puisi yang berorientasi cinta tanah air dapat dilihat pada tabel 1.1 berikut.

\section{Tabel 1}

Data Hasil Analisis Validasi Buku Ajar

\begin{tabular}{|c|c|}
\hline $\begin{array}{c}\text { Validator ahli } \\
\text { Pembelajaran }\end{array}$ & $\begin{array}{c}\text { Validator } \\
\text { Ahli Desain } \\
\text { Grafis }\end{array}$ \\
\hline 83,33 & $75 \%$ \\
\hline
\end{tabular}

Berdasarkan tabel 1 diketahui bahwa skor validasi pengembangan format produksi awal buku ajar menulis puisi dengan berbasis cinta tanah air dari dua validator, yakni ahli pembelajaran bahasa Indonesia dan ahli Desain Grafis, dinilai dalam kategori baik-sangat baik dan layak untuk diujicobakan karena persentasenya $\geq 61 \%$. Selanjutnya untuk mendapatkan kesempurnaan, maka akan dilakukan revisi berdasarkan saran dan komentar dari masing-masing validator, salah satu diantaranya adalah komposisi bentuk lebih variatif dan tidak monoton. Setelah direvisi, maka buku siswa tersebut akan diujicobakan pada tahap uji coba awal.

Uji coba awal menghasilkan data hasil wawancara terhadap guru, observasi oleh pengamat, dan angket siswa yang dikumpulkan dan dianalisis. Uji coba awal diujicobakan kepada tujuh siswa kelas X. Dari beberapa kriteria-kriteria penilain dari wawancara, observasi, dan angket siswa, membuktikan bahwa buku ajar ini sudah layak untuk diujicobakan, tetapi juga masih banyak terdapat kesalahan, contohnya kesalahan dalam penulisan kata, untuk itu perlu direvisi dan akan diujicobakan kembali pada tahap uji coba lapangan.

Uji coba awal ini menghasilkan data kuantitatif dari hasil belajar yang dikumpulkan dan dianalisis sesuai dengan tujuan khusus yang dicapai. Uji coba lapangan diujicobakan kepada 10 siswa kelas X, yang berbeda dengan awal. Data kuantitatif diperoleh hasil penilaian menulis puisi siswa. Kriteria penilaian didasarkan pada teori Burhan Nurgiantoro $(2010,487)$. Hasil nilai siswa adalah sebagai berikut.

Tabel 1.2

Hasil Nilai Siswa Menulis Puisi Tahap Uji Coba Lapangan

\begin{tabular}{|c|l|c|}
\hline No. & \multicolumn{1}{|c|}{ Nama } & Nilai \\
\hline 1. & Atut Budi Nugroho & 76 \\
\hline 2. & Ade Bhaskara hanafi & 80 \\
\hline 3. & Yunita & 80 \\
\hline 4. & Edi Saputra & 76 \\
\hline 5. & Nasruddin Anshori & 80 \\
\hline 6. & Farida Royani & 84 \\
\hline 7. & Agung Dwi Setiawan & 84 \\
\hline 8. & Danar Ari Kuncoro & 84 \\
\hline 9. & Vindyana Achmad Nasrul Adikrhishna & 80 \\
\hline 10. & Feri Nurita & 84 \\
\hline \multicolumn{2}{|}{ Jumlah } & 808 \\
\hline
\end{tabular}


Jadi dapat ditarik simpulan bahwa hasil belajar bidang studi bahasa Indonesia kompetensi dasar menulis puisi dengan berbasis cinta tanah air dianggap berhasil dengan baik menurut pendeskripsian modifikasi skala likert karena rata-rata nilai kelas terletak pada skala interval 61-80.

Uji lapangan ini menghasilkan data wawancara dengan guru, observasi oleh pengamat, dan penyampaian angket siswa. Uji coba lapangan diujicobakan kepada 15 siswa kelas X yang berbeda dengan tahap uji coba sebelumnya. Hasil wawancara dengan guru cenderung ke dalam hal positif, hal ini dibuktikan dalam turunnya hal-hal yang tidak disukai, yaitu 2 hal yang tidak disukai menjadi 1 hal yang tidak disukai dari buku ajar menulis puisi dengan berbasis cinta tanah air. Walaupun demikian tetapi buku ajar ini masih perlu adanya perbaikan dari segi kesalahan kalimat. Hasil observasi oleh pengamat didominasi pada halhal positif, tetapi terdapat beberapa kegiatan siswa yang cenderung negatif seperti masih gaduh di pada saat pelajaran berlangsung. Hasil penyampaian angket siswa menyebutkan bahwa siswa banyak memberikan pandangan positif terhadap buku ajar menulis puisi dengan berbasis cinta tanah air, seperti yang dikemukakan oleh Yunita bahwa buku ajar ini isinya lengkap, kata-katanya menarik, mudah dimengerti, isinya menarik untuk dibaca, dan dilengkapi dengan evaluasi.

Dari hasil uji lapangan tersebut, buku ajar menulis puisi dengan berbasis cinta tanah air masih perlu perbaikan, sebelum diberikan kepada siswa. Dengan demikian setelah direvisi buku ini layak sebagai buku ajar siswa kelas X. Berdasarkan hasil analis data dalam proses pengembangan, dapat disimpulkan bahwa buku ajar menulis puisi dengan berbasis cinta tanah air ini layak untuk diajarkan kepada siswa kelas $\mathrm{X}$ SMA.

\section{Simpulan}

Berdasarkan hasil penelitian dapat diambil simpulan bahwa buku ajar menulis puisi dengan berbasis cinta tanah air yang dikembangkan sudah layak dan memenuhi syarat untuk digunakan sebagai buku ajar menulis puisi kelas X SMA. Hal tersebut dinyatakan sebagai berikut. Pada tahap pertama ini merupakan penelitian dan pengumpulan informasi awal ini, bertujuan untuk mengamati bagaimana kondisi kelas sebelum menyusun buku ajar. Berdasarkan hasil pengamataan, peneliti berhasil mengumpulkan informasi awal yang berkaitan dengan gejala-gejala yang mempengaruhi ketidakberhasilan siswa dalam pembelajaran menulis puisi. Tahap perencanaan yang mencakup mencatat permasalahan saat siswa menulis puisi, menentukan buku ajar, dan uji coba skala kecil yaitu pretest. Hasil dalam tahap perencanaan ini adalah peneliti berhasil mengumpulkan data awal yang berkaitan dengan gejala-gejala yang mempengaruhi ketidakberhasilan siswa dalam pembelajaran menulis puisi. Tahap pengembangan format produksi awal, dalam hal ini adalah pembuatan buku ajar menulis puisi dengan berbasis cinta tanah air dan menilaikan buku ajar kepada dua validator, yaitu validator pembelajaran bahasa Indonesiadan validator desain grafis. Hasil tahap pengembangan format produksi awal adalah skor validasi buku ajar menulis puisi dengan berbasis cinta tanah air dari dua validator, yakni ahli pembelajaran bahasa Indonesia dan ahli Desain Grafis, dinilai dalam kategori baik-sangat baik dan layak untuk diujicobakan karena persentasenya $\geq 61 \%$. Tahap uji coba awal menghasilkan data hasil wawancara terhadap guru, observasi oleh pengamat, dan angket siswa yang dikumpulkan dan dianalisis. Uji coba awal diujicobakan kepada tujuh siswa kelas X. Tahap revisi produk, yang dikerjakan berdasarkan hasil uji coba awal. Hasil uji coba tersebut diperoleh informasi kualitatif tentang produk yang dikembangkan. Hasil revisi produk ini adalah perbaikan terhadap beberapa kelemahan-kelemahan buku ajar yang telah diuji cobakan pada tahap uji coba awal. Tahap uji coba awal ini diujicobakan kepada 10 siswa kelas X. Data kuantitatif diperoleh hasil penilaian menulis puisi siswa. Tahap revisi produk, yang dikerjakan berdasarkan hasil uji coba lapangan. Hasil uji coba lapangan dimaksudkan untuk meningkatkan program atau produk untuk perbaikan pada tahap berikutnya. Kelemahan-kelemahan pada tahap uji coba lapangan yang dilihat dari hasil puisi yang ditulis siswa.Tahap uji lapangan ini menghasilkan data wawancara dengan guru, observasi oleh pengamat, dan penyampaian angket siswa. Tahap revisi produk akhir, yaitu revisi yang dikerjakan berdasarkan uji coba lapangan. Kelemahan-kelemahan dalam tahap uji lapangan akan diperbaiki dalam revisi produk akhir.

\section{Ucapan Terima Kasih}

Terima kasih penulis sampaikan kepada rekan dosen dan pimpinan di Universitas PGRI Madiun atas kontribusinya dalam penelitian ini. 


\section{Daftar Rujukan}

Borg, Walter R dan Gall, Meredith D. Educational Research, Fourth Edition. Longman Inc, 1983. Khan, Yahya. Pendidikan Karakter Berbasis Cinta tanah air. Yogyakarta: Pelangi Publishing, 2010. Koesoema, Doni A. Pendidikan Karakter. Jakarta: Grasindo, 2007.

Nurgiantoro, Burhan. Penilaian Pembelajaran Bahasa. Yogyakarta: BPFE, 2010.

Sagala, Syaiful. Konsep dan Makna Pembelajaran. Bandung: Alfabeta, 2011.

Sudjana, N. Teori Pembelajaran. Bandung: Sinar Baru Algensido, 2001.

Tarigan, Henry Guntur. Menulis Sebagai Suatu Keterampilan Berbahasa. Bandung: Angkasa, 1986. 